\title{
ANTIMICROBIAL SCREENING OF SOME MEDICINAL PLANTS AGAINST SELECTED BACTERIAL SPECIES
}

\author{
Pragya Sapkota,* Sapana Bhattarai,* Anup Muni Bajracharya,* Pramesh Bahadur Lakhe,** \\ Nishant Shrestha** \\ *Department of Microbiology, Balkumari College, Chitwan, Nepal. \\ **Department of Plant Resources, Thapathali, Kathmandu, Nepal.
}

\begin{abstract}
Medicinal plants are used as traditional treatment for numerous human diseases. According to WHO, medicinal plants would be the best source to obtain a variety of drugs. Contrary to the synthetic drugs, antimicrobial of plant origin are not associated with many side effects and have an enormous therapeutic potential to heal many infectious diseases. Present study was carried out on the screening of some medicinal plants against selected pathogenic organisms in the period of October 2017 to January 2018. A total of nine different medicinal plants were screened and evaluated for their antimicrobial activity against 10 bacterial species. Among them, Euphorbia hirta, Azadirachtaindica, Artemisia vulgaris were found to be effective against gram positive bacteria (Bacillus subtilis, Staphylococcus aureus, Methicillin resistant Staphylococcus aureus MRSA), whereas rest six medicinal plants (Aeglemarmelos, Justiciaadhatoda, Ficusreligiosa, Syzygiumcumini, Nyctanthes arbor and Meliaazedarach) were found to be ineffective against all the microorganisms(Bacillus subtilis, Escherichia coli, Klebsiellapneumoniae, Proteus vulgaris, Pseudomonas aerogenosa, Salmonella typhii, Shigelladysentriae, MRSA). The minimum bactericidal concentration (MBC) of Euphorbia hirta against Bacillus subtilis and Staphylococcus aureus was found to be $12.5 \mathrm{mg} / \mathrm{ml}$ and $\mathrm{MBC}$ of Artemisia vulgaris against Bacillus subtilis and MRSA was also found to be $12.5 \mathrm{mg} / \mathrm{ml}$ while of Staphylococcus aureus was $25 \mathrm{mg} / \mathrm{ml}$. Similarly, the MBC of Azadirachta indica against Staphylococcus aureus was $25 \mathrm{mg} / \mathrm{ml}$.
\end{abstract}

Keywords: Medicinal plants; Bacteria; Antimicrobial activity; Minimum bactericidal concentration.

\section{INTRODUCTION}

Medicinal plants have been used in homeopathy, ayurvedic, allopathy and traditional medicine since prehistoric period ${ }^{1}$. According to World Health Organization, $80 \%$ of the population in developing countries depend on traditional medicine for their primary health care and $85 \%$ of traditional medicine is derived from plant. Medicinal properties of plant are due to its active chemical constituents present in different parts of plants. Various phytochemicals like alkaloids, flavonoids, tanins, phlobatannin, terpenoid, saponin, steroid and glycosides are known to show medicinal potential ${ }^{2}$.

Even though pharmacological industries have produced a number of new antibiotics in the last three decades, resistance to these drugs by microorganisms has increased $^{3}$. Today's problem is the increase of bacterial resistance towards different antibiotics that specifically leading to treatment failures and is directly responsible for the current increase in morbidity and mortality associated with bacterial infections. Multi-drug resistance bacteria have emerged throughout the world causing several problems, clinical infections ${ }^{3}$. The increasing prevalence of multidrug resistant strains of bacteria and the recent appearance of strains with reduced susceptibility to antibiotics raises the specter of untreatable bacterial infections and adds urgency to the search for new infection-fighting strategies ${ }^{4}$. There is a rich local ethnobotanical bibliography in Nepalese traditional medicine; however, there is a lack of experimental scientific studies confirming the possible antibiotic properties of a great number of these medicinal plants ${ }^{5}$. Medicinal plants may be used to solve the problem of emerging resistance of microorganisms. Therefore, in this study we made an attempt to assess the antimicrobial properties of medicinal plants against some selected pathogenic microorganisms.

\section{MATERIALS AND METHODS}

\subsection{Plant collection:}

The plant material (leaves) were collected from local areas of Nawalparasi district and were identified according to various literatures like Medicinal plants of Nepal by HMG/N (1993), Ethnobotany of Nepal ${ }^{6,7}$ and including other pertinent taxonomic literature. The list of medicinal plants, their corresponding parts used in this study, month of sample collection and location/place of the sample plants were given in Table1.

\subsection{Sample processing:}

The leaves of the medicinal plants were properly washed in the tap water. The rinsed leaves were then dried in shade region where there was no direct exposure of sunlight, for 4-5 days. The dried leaves of each plant were crushed to obtain powder. These powdered samples were stored in airtight polythene bags protected from sunlight until use.

\subsection{Preparation of extract:}

After completion of collection, drying and grinding then these plant materials were extracted by soxhlet extraction using 70\% ethanol as a solvent. Then, the solvent was distilled under reduced pressure in a rotary vacuum evaporator and water bath at $65^{\circ} \mathrm{C}$ until the extract 
became dry. The percentage yield for each extract was determined and the crude extract was then transferred in a sterile vial by sterile spatula. One gram crude ethanol extract from each medicinal plant was mixed with $9 \mathrm{ml}$ of $70 \%$ ethanol and vortexed to make homogenous mixture of $1 \mathrm{~g} / 10 \mathrm{ml}$ i.e. $100 \mathrm{mg} / \mathrm{ml}$ working suspension and stored in a refrigerator at $2-8^{\circ} \mathrm{C} .{ }^{5}$

\subsection{Microorganism:}

The strain of microorganism used were Bacillus subtilis ATCC 6051, Escherichia coliATCC8739, Enterococcusfaecalis ATCC 29212, Klebsiellapneumonia ATCC700603, Pseudomonasaeruginosa ATCC9027, Proteus vulgaris ATCC 6380, Staphylococcusaureus ATCC6538P, Shigelladysentriae clinical sample, Salmonella typhi clinical sample and Methicillin Resistant Staphylococcusaureus clinical sample. The entire microorganisms were maintained in $4^{\circ} \mathrm{C}$ on Nutrient agar plate.

\subsection{Antibacterial activity}

The crude extract of medicinal plants was screened for its antibacterial property i.e, determination of zone of inhibition against tested bacteria was done by agar well diffusion method. The fresh bacterium culture comparable with turbidity standard i.e McFarland turbidity standard was prepared and swabbed on the surface of MullerHinton agar plates (MHA). Well of diameter $6 \mathrm{~mm}$ were made in the inoculated MHA media plate. To evaluate the efficiency of methodology, $50 \mu \mathrm{l}$ of each working solution of extract was transferred into the well and the plates were incubated at $37^{\circ} \mathrm{C}$ for 24 hours. After this period, it was possible to observe zone of inhibition, if the plate showed zone of inhibition then minimum bactericidal concentration (MBC) was carried out by two-fold serial dilution $\operatorname{method}^{5}$.

\section{RESULTS}

Considering the ethanol extracts of the examined medicinal plants, the percentage yield of $70 \%$ ethanol extracts of medicinal plants obtained by soxhlet extraction was as shown in Figure 1. The yield varied among the medicinal plants, Euphorbia hirta gave the highest yield (27.14\%) while Artemisia vulgaris gave the lowest yield $(8.86 \%)$.

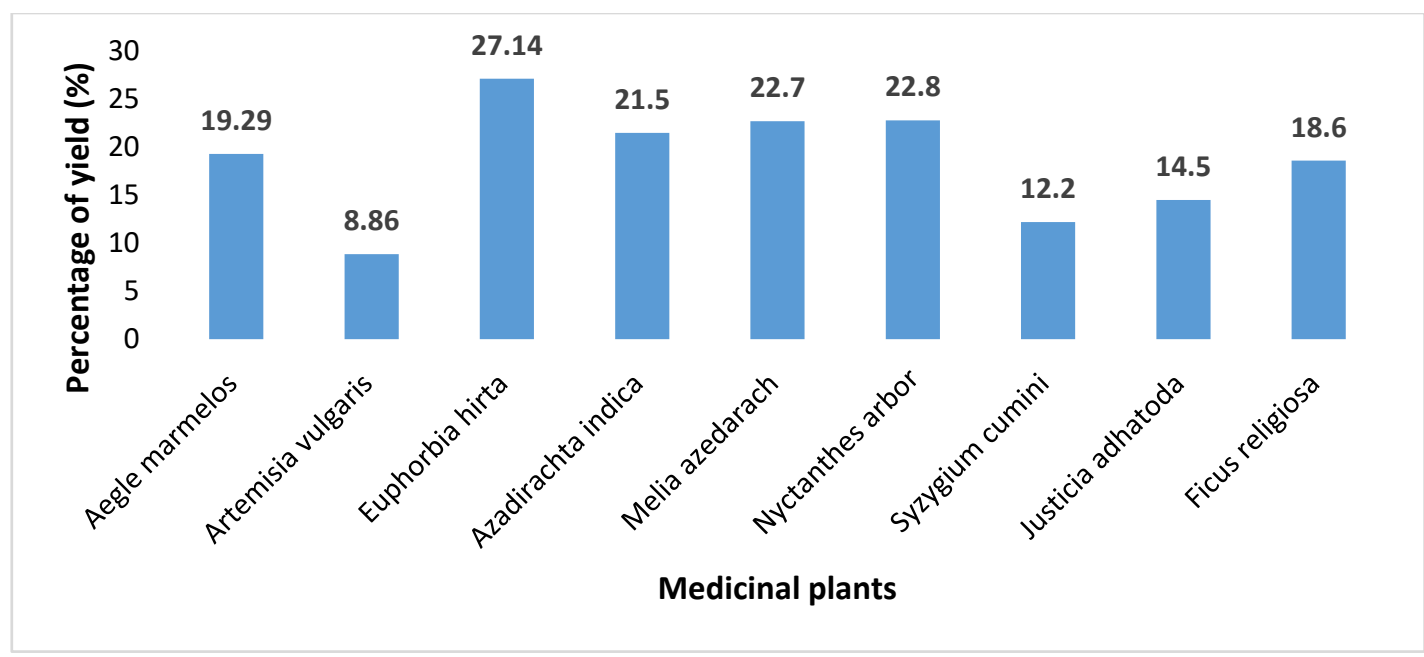

Figure: 1. Percentage yield of $70 \%$ ethanolic extracts.

Nine different medicinal plants were used for the study (Table 1). Similarly, Table 2 reflects the antibacterial activity shown by plant extracts through agar- well diffusion method. The plant extracts of Artimisia vulgaris and have lethal effect on B subtilis, S aureus and
MRSA whereas Euphorbia hirta have its effect on $B$ subtilis, $S$ aureus and Azadirachtaindica have its lethal effect on S aureus and MRSA. Table 3 depicts the zone of inhibition and minimum bactericidal concentration of medicinal extracts against some pathogenic bacteria.

Table: 1. List of medicinal plants used in antimicrobial screening

\begin{tabular}{|c|c|c|c|c|c|c|c|}
\hline \multicolumn{10}{|c|}{ List of medicinal plants } \\
\hline SN & Local name & Botanical Name & Family & Part used & Month of collection & Location & District \\
\hline 1 & Parijhat & Nyctanthes arbor & Oleaceae & leaves & September/October & Kawosoti & Nawalparasi \\
\hline 2 & Dodhejhar & Euphorbia hirta & Euphorbiaceae & whole shoot & September & Kawosoti & Nawalparasi \\
\hline 3 & Neem & Azadirachtaindica & Meliaceae & leaves & September & Gaindakot & Nawalparasi \\
\hline 4 & Jamun & Syzygiumcumini & Myrtaceae & leaves & September/October & Kawosoti & Nawalparasi \\
\hline 5 & Titepati & Atrtemisis vulgaris & Asteraceae & leaves & September/October & Kawosoti & Nawalparasi \\
\hline 6 & Peepal & Ficusreligiosa & Moraceae & leaves & September/October & Gaindakot & Nawalparasi \\
\hline 7 & Asuro & Justicaadhatoda & Acanthaceae & leaves & September/October & Gaindakot & Nawalparasi \\
\hline 8 & Bakaino & Meliaazedarach & Meliaceae & leaves & September/October & Gaindakot & Nawalparasi \\
\hline 9 & Bel & Aeglemarmelos & Rutaceae & leaves & September/October & Gaindakot & Nawalparasi \\
\hline
\end{tabular}


Table: 2. Antibacterial activity shown by plant extracts through Agar-well diffusion. (+) Susceptibility ( Inhibition zone $>8 \mathrm{~mm}$ ) (-) Absence of susceptibility

\begin{tabular}{|c|c|c|c|c|c|c|c|c|c|c|c|}
\hline S.N. & Medicnal plants & $\frac{\underset{5}{5}}{\underset{5}{5}}$ & 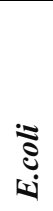 & 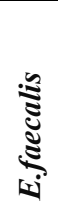 & 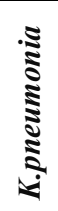 & 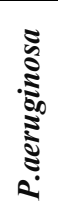 & 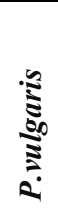 & $\underset{\substack{\vdots \\
\vdots}}{\mathfrak{s}}$ & 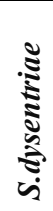 & 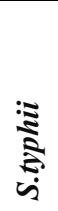 & Е \\
\hline 1 & Aeglemarmelos & - & - & - & - & - & - & - & - & - & - \\
\hline 2 & Artimisia vulgaris & + & - & - & - & - & - & + & - & - & + \\
\hline 3 & Eupharbiahirta & + & - & - & - & - & - & + & - & - & - \\
\hline 4 & Azadirachtaindica & - & - & - & - & - & - & + & - & - & + \\
\hline 5 & Meliaazedarach & - & - & - & - & - & - & - & - & - & - \\
\hline 6 & Nyctanthes arbor & - & - & - & - & - & - & - & - & - & - \\
\hline 7 & Syzygiumcumini & - & - & - & - & - & - & - & - & - & - \\
\hline 8 & Justicaadhatoda & - & - & - & - & - & - & - & - & - & - \\
\hline 9 & Ficusreligiosa & - & - & - & - & - & - & - & - & - & - \\
\hline
\end{tabular}

Table: 3. Antimicrobial activity of crude ethanol extracts.

\begin{tabular}{|c|c|c|c|c|c|c|c|}
\hline S.N. & Test organisms & \multicolumn{6}{|c|}{ Antimicrobial activity } \\
\hline \multirow[t]{3}{*}{1.} & \multirow[t]{3}{*}{ S. aureus } & \multicolumn{2}{|c|}{ Artemisia vulgaris } & \multicolumn{2}{|c|}{ Euphorbia hirta } & \multicolumn{2}{|c|}{ Azadirachtaindica } \\
\hline & & ZOI (mm) & $\mathrm{MBC}(\mathrm{mg} / \mathrm{ml})$ & ZOI (mm) & $\mathrm{MBC}(\mathrm{mg} / \mathrm{ml})$ & $\mathrm{ZOI}(\mathrm{mm})$ & $\begin{array}{c}\mathrm{MBC}(\mathrm{mg} / \\
\mathrm{ml})\end{array}$ \\
\hline & & 18.60 & 25 & 14.84 & 12.5 & 14.4 & 25 \\
\hline 2. & MRSA & 14 & 12.5 & - & - & 20.47 & 25 \\
\hline 3. & B. subtilis & 9.6 & 12.5 & 14.89 & 12.5 & - & - \\
\hline
\end{tabular}

The maximum zone of inhibition was observed in case of Methicillin resistant Staphylococcus aureus (MRSA) $(20.47 \mathrm{~mm})$ due to the action of Azadirachtaindica and minimum was against Bacillus subtilis $(9.6 \mathrm{~mm})$ shown by Artemisia vulgaris. The minimum bactericidal concentration (MBC) of the three plants against Staphylococcus aureus, MRSA, Bacillus subtilis were found to between $12.5-25 \mathrm{mg} / \mathrm{ml}$.

\section{DISCUSSION}

The results bring to light that each medicinal plant shows various degree of inhibition against different microorganisms. The diameter of zone of inhibition produced depends on several factors broadly classified as extrinsic and intrinsic parameters. The extrinsic parameters like $\mathrm{pH}$ of the medium, period and temperature of incubation, volume of well, concentration of plant extracts and size of inoculums can be fixed and standardized during experiment. However, intrinsic factors such as nature of medicinal plants including its components, solubility and diffusing property are predetermined ${ }^{5}$.

The results from Table 2 suggests that only three of the medicinal plant extract viz. Artemisia vulgaris, Euphorbia hirta and Azadirachtaindica had activity against three different microorganisms, Staphylococcus aureus, MRSA and Bacillus subtilis. This inhibitory effect shown in the study refers that extracts having high antimicrobial activity against gram positive bacteria doesn't necessarily have activity against gram negative bacteria. Antibacterial activity due to Azadirachtaindica was previously reported ${ }^{8}$.Similarly, activity due to Euphorbia hirta was also reported ${ }^{9}$. The antibacterial activity of medicinal plants against gram-positive bacteria was studied in different studies. For instance, I.E. Cock studied the antibacterial effects of 39 methanol extracts of 25 Australian herbs against two gram-positive bacteria of Bacillus cereus and Bacillus subtilis and two gramnegative bacteria of Pseudomonas aeruginosa and Aeromonashydrophila, the disk diffusion method was used. The results showed the sensitivity of gram-positive bacteria $^{10}$. In addition, Joshi et al mentioned the antibacterial effects of ten different medicinal plant extracts of Nepal. The plant extracts were more active against Gram-positive bacteria than against Gramnegative bacteria. The most susceptible bacteria were $B$. subtilis, followed by $S$. aureus, while the most resistant bacteria were E.coli, followed by Shigelladysenteriae, Klebsiellapneumoniae and Salmonella typhi. ${ }^{11}$.

Ten important human pathogenic bacteria were investigated and the well method was used. Extracts were more effective in gram-positive bacteria compared to gram-negative bacteria. The most sensitive bacteria were Bacillus subtilis and Staphylococcus aureus and the most resistant bacteria were $E$. coli, Shigelladysenteriae, 
Klebsiellapneumoniae and Salmonella typhimurium ${ }^{11}$.In fact, gram-positive bacteria are more sensitive to herbal extracts than gram-negative bacteria. This may be because of inherent tolerance of gram negative and the nature and composition of herbs. According to the studies, the cell wall of gram-positive bacteria compared with gramnegative bacteria, are more sensitive to many of antibiotics, antimicrobial chemical compounds ${ }^{12}$ and even many herbal drugs ${ }^{13}$. Lipopolysaccharides layer and periplasmic space of gram-negative bacteria are the reasons of relative resistance of gram-negative bacteria.

\section{CONCLUSIONS}

The plant extracts have great potential as antimicrobial compounds against microorganisms. Our research study revealed that plants like Artemisia vulgaris, Euphorbia hirta and Azadirachtaindica have great therapeutic potential against some diseases. Further researches can be done to discover major group of phytochemical compounds that open the possibility of finding new clinically effective antibacterial compounds.

\section{ACKNOWLEDGEMENTS}

Acknowledgements are due to Department of plant resources, Thapathali, Kathmandu and Department of Microbiology, Balkumari College, Narayangarh, Chitwan for the laboratory facilities and instruments provided by them.

\section{REFERENCES}

1. Sharma, S. \& Devkota,A. 2015. Allelopathic potential and phytochemical screening of four medicinal plants of Nepal. Scientific World. 12(12):56-61.

2. Dipak, Ket. al.2010. Phytochemical screening of eight traditionally used ethnomedicinal plants from Akola District India. International Journal of Pharma and Bio Sciences. 1(4).

3. Nascimentom, G.G.F. et. al.2000. Antibacterial activity of plant extracts and phytochemicals on antibiotic resistant bacteria.Brazilian journal of microbiology. 31:247-56.

4. Sieradzki, K. et. al. 1999. The development of vancomycin resistance in a patient with methicillin-resistant Staphylococcus aureus infection. N. Engl. J. Med. 340: 517-523

5. Bajracharya, A. M. et. al. 2008. Screening of some medicinal plants used in Nepalese traditional medicine against enteric bacteria. Sci. World. 6: 107-10.

6. HMG/N. 1993. Medicinal Plants of Nepal. Ministry of Forest and Soil Conservation, Department of Plant Resources. Kathmandu, Nepal.

7. Rajbhandari, R.K. 2001. Medicinal Plants. In: Ethnobotany of Nepal. Ethnobotanical Society of Nepal. p 98-134.

8. Thakurta, P. et. al. 2007. Antibacterial, antisecretory and antihemorrhagic activity of Azadirachtaindica used to treat cholera and diarrhea in India. Journal of ethnopharmacology. 111(3): 607612.

9. Abubakar, E. M. M. 2009. Antibacterial activity of crude extracts of Euphorbia hirta against some bacteria associated with enteric infections. Journal of Medicinal Plants Research. 3(7): 498-505.

10. Cock, IE.2008.Antibacterial Activity of Selected Australian Native Plant Extracts. The Internet Journal of Microbiology. 4,2:1-8.

11. Joshi,B.,Lekhak, S. and Sharma, A. 2009.Antibacterial Property of Different Medicinal Plants: Ocimum sanctum, Cinnamomumzeylanicum, Xanthoxylumarmatum and Origanummajorana. Nepal Journals Onliney.5, 1:143-150.

12. Kittika, N. Natta, L. and Orapian, K. 2007. Antibacterial Effect of Five Zingiberaceae Essential Oils. Molecules. 12,8.

13. Sharifa, A. A et. al.2008. Effects of Methanol, Ethanol and Aqueous Extract of Plantago major against Gram Positive Bacteria, Gram Negative Bacteria and Yeast, Annals of Microscopy. 8:42-44. 